\title{
Bioflavonoids as Important Component of Biological Protection from Ionizing Radiation
}

\author{
Mikhail V. Vasin \\ Department of Medicine Catastrophe, Russian Medical Academy of Post-Graduated Education, Moscow, Russia. \\ Email: mikhail-v-vasin@yandex.ru
}

Received October 31 ${ }^{\text {st }}$, 2013; revised December $1^{\text {st }}$, 2013; accepted December $8^{\text {th }}, 2013$

Copyright (C) 2014 Mikhail V. Vasin. This is an open access article distributed under the Creative Commons Attribution License, which permits unrestricted use, distribution, and reproduction in any medium, provided the original work is properly cited. In accordance of the Creative Commons Attribution License all Copyrights (c) 2014 are reserved for SCIRP and the owner of the intellectual property Mikhail V. Vasin. All Copyright (C) 2014 are guarded by law and by SCIRP as a guardian.

\begin{abstract}
New advances in the area of deciphering the mechanism for a possible modification of the biological effects of radiation exposure at the genetic level make it possible to distinguish the group of radiation protective agents having their own specific features in the implementation of their beneficial effects. The mechanism of the radioprotective action of bioflavonoids is worthy of a detailed analysis in view of their great biological importance. Radiobiological studies show that antioxidants can reduce the radiation damage to membranes and favor more adequate energy dependent adaptive and reparative processes after the exposure to radiation. Bioflavonoids are significant component of "biological protection" for a enhance of resistance of the body to environmental factors that are adverse for human health, including ionizing radiation, with reducing the risk of carcinogenic effects and decreasing the biological age. The best practical value of bioflavonoids, can be considered as the agents for prophylaxis against the development of oxidative stress. These are the reasons why the administration of natural antioxidants have a pathogenetic justification for exposures to chronic (months, years) low-rate-dose ionizing radiation. These agents were previously and are currently being developed for use during long-term, low-ratedose exposures to radiation, under conditions of long space missions. Acting as low-dose stressors through a hormetic mechanism and a "substrate" support of adaptive shifts radiomodulators results in an increase in the antioxidant defense of the body and the rearrangement of its functioning in the new environment with the modulation of gene expression of antioxidant response elements by activation of Nrd2/KeapI and Sirtuin/FoxO pathways and a decrease in the transcription factor NF- $\kappa$ B.
\end{abstract}

\section{KEYWORDS}

Bioflavonoids; Antioxidants; Radiation Protective Agents; Radiomodulators; Low-Dose-Rate Irradiation

\section{Introduction}

Preventive medicine gives a lot of attention to the role of antioxidants, especially of the natural origin. Radiobiological studies show that antioxidants can reduce the radiation damage to membranes and favor more adequate energy dependent adaptive and reparative processes after the exposure to irradiation. It is important to emphasize that the organism responds to the radiation damage, as to any influence of stress, by mobilizing the antioxidant system. Under conditions of the long-term low-level exposure to radiation, when the antioxidant system of the organism is exhausted, the administration of natural water soluble and fat soluble antioxidants can act as a sub- strate treatment aimed at compensating the increased need for these compounds [1-3].

Bioflavonoids (natural plant flavonoids, semi-essential nutrients, vitamin P) are significant component of "biological protection” [4,5] for a enhance of resistance of the body to harmful environmental factors, including ionizing radiation, with reducing the risk of carcinogenic effects and decreasing the biological age $[6,7]$.

Flavonoids are the products of the plant vital activity. Tea leaves, buckwheat, Sophora japonica, citrus fruits, rose hips and black chokeberry are especially rich in them. Substantial amounts of flavonoids are contained in black currants, strawberries, raspberries, cherries, sea 
buckthorn, some sorts of apples, plums and grapes.

Flavonoids are plant polyphenols. The most important are flavan-3-ols (catechins), flavonols, flavones, neoflavonones, anthocyanidins, leucoanthocyanidins (flavandiols-3,4), and also chalcone derivatives, dehydrochalcone and aurone. About 4000 flavonoids have been described. Flavonoids are water-soluble or lipophilic compounds with yellow, orange and red color. Anthocyanines and aurones are plant pigments, and colour flowers and fruits. Humans need several hundred milligrams of bioflavonoids (vitamin P) per day.

In plants, they exist in the form of glycosides and rutinosides. In plants, flavonoids protect the photosynthetic apparatus of the cell against reactive oxygen species during the exposure to the short-wave UV radiation and other forms of oxidative stress (frost, drought, extreme fluctuations of the environmental temperature, etc.) $[8,9]$. It should be noted that plants growing in the areas contaminated by fallout from Chernobyl have an increased production of anthocyans [10]. In addition, flavonoids are referred to as protective agents in the plants which are affected by pathogens.

The tissues of the body contain ascorbic acid at a certain concentration; cell membranes contain tocopherols. There is a recirculation of the oxidized and reduced forms of these natural antioxidants, which supports the antioxidant protection of cell membranes. It involves flavonoids, which are the most powerful antioxidants, and the antioxidant system of cells as a whole. Flavonoids reduce ascorbic acid and they also readily form complexes with metal ions, as well as have the antimutagenic activity. Flavanols, flavonols and flavonons inhibit lipid peroxidation [11], including that induced by ionizing radiation, starting with the concentration of more than 10 mcM [12]. Plant flavonoids several times exceed endogenous and exogenous antioxidants in the tissues of animals and humans (vitamin E, glutathione, ascorbic acid, beta-carotenoids) in their antiradical activity [13, 14]. The unquestionable synergetic effect was observed in quercetin with glutathione and ascorbic acid [15]. The flavonoids possess anti-inflammatory, antioxidant, antiallergic, hepatoprotective, antithrombotic, antiviral, and anti-carcinogenic activities [16].

\section{Anti-Radiation Effect of Bioflavonoids}

Flavonoids mitigate the radiation damage to DNA in vitro which is registered by the reduction of chromosomal aberrations (CA) in the bone marrow, in all probability, due to their anti-radical activity [17]. Quercetin is able to accumulate in mitochondria and bind to the DNA molecule [18].

The mechanism for the action in vitro of dry wine is the same, primarily due to catechins (30 - $100 \mathrm{mg} / \mathrm{L})$ and procyanidins from the grape seeds which are found in its composition $[19,20]$. Alcohol in the composition of dry wine does not prevent the realization of the effect of bioflavonoids. Catechins from tea also reduce the DNA damage, with epigallocatechin from green tea being the most active (in the ratio of up to $400 \mathrm{mg} / \mathrm{L}$ ) [21,22]. A similar action is typical for flavonones naringenin from grapefruit [23], apigenin [24], luteolin [25], and lignans [26].

Radiation protective effects of flavonoids on the reduction of the CA levels of the bone marrow were also observed in the experiments in vivo when they were used before and after exposures of mice to irradiation $[27,28]$. Bioflavonoids can exert a radiation protective effect detected by the test of the increased survival rate of animals exposed to lethal doses of radiation. This result was obtained following the administration of anthocyanins [29] and isoflavone genistein [30,31], flavonol quercetin [32] and the extract from the fruit of black chokeberry [33]. The radiation protective effect of genistein is associated with the induction of G-CSF and IL-6 [34]. Genistein can have a favorable effect on the reduction of the radiation damage to the lungs [35].

The best practical value of bioflavonoids, can be considered as the agents for prophylaxis against the development of oxidative stress. These are the reasons why the administration of natural antioxidants have a pathogenetic justification for exposures to chronic (months, years) low-rate-dose ionizing radiation $[2,36]$. These agents were previously and are currently being developed for use during long-term, low-rate-dose exposures to radiation, under conditions of long space missions [37-40]. Since these substances have low toxicity and do not have side effects at the administered doses, they can be used repeatedly, lifelong if necessary, with alterations in the cycles of metabolic correction and substrate therapy depending on the appearance of symptoms of chronic oxidative stress. The realization of the action of natural antioxidants takes a certain period of time, so the effect is enhanced following the repeated their administration [41]. A peculiar feature of pharmaco-dynamics of the preparations comprising the "biological shield" is that the modifications in the radiation resistance of the organism under their impact do not happen immediately, but gradually over repeated administration, more often within 2 weeks, and can be maintained at the elevated level during the entire course of treatment and prevention $[42,43]$. When the preventive measures are well tolerated, they can be repeated without any loss of their effectiveness.

\section{The Mechanism of Protective Effectiveness of Bioflavonoids against Ionizing Radiation Exposure}

The theoretical basis for the research into the mechanism of increasing the resistance of the organism to environ- 
mental chronic stress under the influence of pharmacological agents is from a classic study by Selye [44] and additional research in this area, including studies investigating into the formation of different adaptive stages, depending on the strength and duration of the impact of adverse environmental factors [45-47].

The fundamentally important characteristic feature of the pharmacological agents that enhance the nonspecific resistance of the organism is the fact that their optimal effect can be formed due to the slowly proceeding structural rearrangements manifesting themselves as the alteration and complication of the adaptive phases of "activation" and "training" supported by the definite rhythm of repeated exposures to low doses of an adaptogen [45].

Acting as low-dose stressors through a hormetic mechanism and a "substrate" support of adaptive shifts radiomodulators results in an increase in the antioxidant defense of the body and the rearrangement of its functioning in the new environment with the modulation of gene expression of antioxidant response elements by activation of Nrd2/KeapI and Sirtuin/FoxO pathways and a decrease in the transcription factor NF- $\kappa \mathrm{B}$ [48-50]. According to their action, these agents are to some extent opposite to drugs noted in [1] as classical mitigators (e.g., vaccines, LPS, pro-inflammatory cytokines) which have pro-inflammatory properties and whose mechanism is based on the activation of the transcription factor NF- $\kappa \mathrm{B}$ (Table 1).

The repeated administration of vitamin complexes results in the increase of the body resistance to harmful environmental factors, including radiation exposure. This is associated with the activation of the pituitary-adrenal system. For example, ascorbic acid, whose action is stimulated by flavonoids, is a cofactor for the synthesis of adrenaline and glucocorticoids [51,52]. The basis of the pathogenetic mechanism for their action lies in the stimulation of the neuro-immuno-endocrine system with the activation of individual axes of regulation (pituitaryadrenal, hypothalamic-thymic, and pituitary-thyroid), whose predominance depends on the nature, dose, and pattern of administration of a pharmaceutical agents. Of example, estrogenic flavonoids (genistein) have immunostimulant action [53,54]. A direct substrate regulation of the antioxidant system and biosynthetic processes, which are important for the post-radiation reparation of the tissues of the body, is also possible when natural antioxidants are used as nutrient supplements-vitamins, nucleotides, oligo-peptides, amino acids, and other compounds. However, in this case system reactions affecting the neuro-immuno-endocrine regulation in the organism are inevitable.

Dietary antioxidants such as vitamins A, C, and E, polyphenols, anthocyanins, flavonoids, isothiocyanates,
Table 1. The mechanisms and conditions of realization of radiation protective effect of flavonoids.

\begin{tabular}{|c|c|c|}
\hline $\begin{array}{l}\text { Pharmacological } \\
\text { properties }\end{array}$ & $\begin{array}{l}\text { The mechanisms of } \\
\text { anti-radiation action }\end{array}$ & $\begin{array}{l}\text { The condition of } \\
\text { realization of } \\
\text { protective effect }\end{array}$ \\
\hline Antioxidant & $\begin{array}{l}\text { Enzyme and } \\
\text { non-enzyme anti-radical } \\
\text { effect, activation of } \\
\text { Nrf2/KeapI and } \\
\text { Sirtuin/FoxO pathway }\end{array}$ & $\begin{array}{l}\text { Low-dose-rate } \\
\text { irradiation, repeated } \\
\text { prophylactic dose of } \\
\text { drugs and nutrient } \\
\text { supplement }\end{array}$ \\
\hline Pro-oxidant & $\begin{array}{l}\text { Activation the NF- } \kappa \mathrm{B} \\
\text { pathway, increase of } \\
\text { pro-inflammatory } \\
\text { cytokines } \rightarrow \text { stimulant } \\
\text { effect of myelopoiesis }\end{array}$ & $\begin{array}{l}\text { High-dose-rate and } \\
\text { lethal irradiation, } \\
\text { overdose of drugs, } \\
\text { delayed protective } \\
\text { effect }\end{array}$ \\
\hline Estrogenic & $\begin{array}{l}\text { Immunostimulant action, } \\
\text { G-CSF increase } \rightarrow \\
\text { stimulant effect of } \\
\text { myelopoiesis }\end{array}$ & $\begin{array}{l}\text { High-, low-dose-rate, } \\
\text { and lethal, non-lethal } \\
\text { irradiation, therapeutic } \\
\text { dose of drugs, } \\
\text { delayed protective } \\
\text { effect }\end{array}$ \\
\hline Anti-carcinogenic & $\begin{array}{l}\text { Inhibition the NF- } \kappa \mathrm{B} \\
\text { pathway, and the } \\
\text { mutation or } \\
\text { hyper-expression of the } \\
\text { Nrf2-Keap1 signaling } \\
\text { pathway in tumor } \\
\text { genesis, and } \\
\text { angiogenesis }\end{array}$ & $\begin{array}{l}\text { Low-dose-rate } \\
\text { irradiation, repeated } \\
\text { prophylactic dose of } \\
\text { drugs and nutrient } \\
\text { supplement }\end{array}$ \\
\hline Anti-inflammatory & $\begin{array}{l}\text { Inhibition the NF- } \kappa \mathrm{B} \\
\text { pathway, } \\
\text { pro-inflammatory } \\
\text { cytokine decrease } \rightarrow \\
\text { mitigation of } \\
\text { post-radiation fibrosis of } \\
\text { tissues }\end{array}$ & $\begin{array}{l}\text { High-, low-dose-rate, } \\
\text { and non-lethal } \\
\text { irradiation, therapeutic } \\
\text { dose of drugs, delayed } \\
\text { protective effect }\end{array}$ \\
\hline
\end{tabular}

and other natural antioxidants are considered as impacting redox reactions [55,56]. Those with high oxidant potential can directly interact with radiation-induced radicals; this has been recently considered as a basic mechanism of their radioprotective action [57-59].

However, natural antioxidants, in all probability, participate in the gene regulation of the antioxidant system of the organism. Their indirect involvement as antioxidants can be achieved by means of inhibition of the redox-sensitive transcription factors (NF- $\kappa \mathrm{B}$, activator protein-1) and pro-oxidant enzymes (iNOS, cyclooxygenase, xanthine oxidase) through the induction of antioxidant enzymes (glutathione peroxidases, superoxide dismutase), and phase II of cellular respiration. Experiments in vitro revealed that genistein and quercetin are able to significantly increase the gene promoter activity of glutathione peroxidase and superoxide dismutase in the absence of the effect on the activity of catalase [60]. Genistein also increased the expression of metallothionein genes [61]. Quercetin inhibits the synthesis of iNOS through the inhibition of NF- $\kappa$ B and STAT1 [49] and suppresses the growth of xenograft A2780S ovarian tumors by causing cancer cell apoptosis and inhibition of angiogenesis in 
vivo [62]. Genistein induces antiangiogenesis and antimetastatic effects, and cell cycle arrest [63]. The mechanism of anti-carcinogenic action of flavonoids closely is connected with inhibition of the mutation or hyperexpression of the NF- $\kappa \mathrm{B}$, and the Nrf2-Keap1 signaling pathway in tumor genesis [64].

Anti-inflammatory properties of flavonoids are caused by selectively block of nuclear NF- $\kappa$ B transactivation of specific target genes (in particular IL-6) via attenuation of mitogen-activated protein/extracellular signal-regulated kinase (ERK) kinase (MEK) and ERK activity [65].

Drugs with NF- $\kappa$ B pathway suppressive and anti-inflammatory actions, such as angiotensin-converting enzyme and prostaglandin biosynthesis inhibitors, and melatonin, and isoflavone genistein can mitigate post-radiation fibrosis of kidney, lungs, skin, and post-radiation myelosuppression of ARS [66-72].

As any antioxidants, flavonoids can show pro-oxidant action under certain condition (for example, high dose of drugs and the exhaustion of antioxidant enzyme network) [73]. This effect may induce NF- $\kappa$ B activation with following increase pro-inflammatory cytokines which have radiation protective and mitigable action [74].

\section{Conclusion}

The favorable action of natural antioxidants in the presence of the chronic oxidative stress is the reduction in the intensity and time needed to implement the remote impact of radiation damage to particular tissues and systems, primarily associated with their important role in the functioning of the vascular system. This prevents the development of atherosclerosis, disorders of the microcirculation in tissues and their fibrosis, and the manifestation of chronic inflammatory processes in the patients with the immune system disorders; in other words, premorbid states leading to, as noted above, cardiovascular and endocrine diseases and the progression of carcinogenesis [75]. It is also known that the bioflavonoids epigallakatehin-3-gallate, luteolin, quercetin, kaempferol, apegenin, and taxifolin are able to block the fatty acid synthase, which is the basis for the anti-carcinogenic action of these compounds [76]. Antioxidants (quercetin, vitamins $\mathrm{A}$ and $\mathrm{C}$, beta-carotene, selenium, melatonin, and glutathione) are used in clinical practice as radiomodulators during the radio-chemotherapy of cancer patients [77]. New advances in the area of deciphering the mechanism for a possible modification of the biological effects of radiation exposure at the genetic level make it possible to distinguish the group of radiation protective agents having their own specific features in the implementation of their beneficial effects. The mechanism of the radioprotective action of bioflavonoids is worthy of a detailed analysis in view of their great biological importance [78].

\section{Acknowledgements}

The research cited in this article was from publications through October 2013. The opinions contained in this paper are the views of the author.

\section{Declaration of Interest}

The author reports no conflicts of interest and is alone responsible for the content and writing of this paper.

\section{REFERENCES}

[1] M. V. Vasin, "Classification of Agents of Radiation Damage Prophylaxis as Formation of Conceptual Basis of Modern Radiation Pharmacology,” Radiatsionnaia Biologiia Radioecologiia, Vol. 29, No. 2-3, 1999, pp. 212222.

[2] K. N. Prasad, "Rationale for Using Multiple Antioxidants in Protecting Humans against Low Doses of Ionizing Radiation,” British Journal of Radiology, Vol. 78, No. 930, 2005, pp. 485-492. http://dx.doi.org/10.1259/bjr/87552880

[3] R. Arora, "Herbal Radiomodulators: Applications in Medicine, Homeland Defence and Space,” CABI, Cambridge, 2008.

http://dx.doi.org/10.1079/9781845933951.0000

[4] P. P. Saksonov, V. V. Antipov and B. I. Davydov, "Outline of Space Radiobiology. Problems of Space Biology,” National Aeronautics and Space Administration (NASA), Washington, 1972.

[5] P. P. Saksonov, "Protection against Radiation (Biological, Pharmacological, Chemical, Physical),” In: P. P. Saksonov, Ed., Foundation of Space Biology and Medicine, Vol. 3, National Aeronautics and Space Administration, Washington, 1975, pp. 316-347.

[6] T. P. Devasagayam, J. C. Tilak, K. K. Boloor, K. S. Sane, S. S. Ghaskadbi and R. D. Lele, "Free Radicals and Antioxidants in Human Health: Current Status and Future Prospects,” Journal of Association of Physicians of India, Vol. 52, 2004, pp. 794-804.

[7] M. W. Epperly, H. Wang, J. A. Jones, T. Dixon, C. A. Montesinos and J. S. Greenberger, "Antioxidant-Chemoprevention Diet Ameliorates Late Effects of Total-Body Irradiation and Supplements Radioprotection by MnSODPlasmid Liposome Administration,” Radiation Research, Vol. 175, No. 6, 2011, pp. 759-765. http://dx.doi.org/10.1667/RR2398.1

[8] V. A. Baraboi, "Biological Action of Vegetable Phenol Compounds,” Nauka Dumka, Kiev, 1976.

[9] T. Nagata, S. Todoriki, T. Masumizu, I. Suda, S. Furuta, Z. Du and S. Kikuchi, "Levels of Active Oxygen Species Are Controlled by Ascorbic Acid and Anthocyanin in Arabidopsis," Journal of Agricultural Food and Chemistry, Vol. 51, No.10, 2003, pp. 2992-2999. http://dx.doi.org/10.1021/jf026179+

[10] N. I. Gushcha, G. I. Perkovskaia, A. P. Dmitriev and D. M. Grodzinskii, "The Influence of Chronic Irradiation on Adaptive Potential of Plants,” Radiatsionnaia Biologia 
Radioekologia, Vol. 42, No. 2, 2002, pp. 155-158.

[11] Y. J. Jeong, Y. J. Choi, H. M. Kwon, S. W. Kang, H. S. Park, M. Lee and Y. H. Kang, "Differential Inhibition of Oxidized LDL-Induced Apoptosis in Human Endothelial Cells Treated with Different Flavonoids,” British Journal of Nutrition, Vol. 93, No. 5, 2005, pp. 581-591. http://dx.doi.org/10.1079/BJN20041397

[12] P. Uma Devi, A. Ganasoundari, B. Vrinda, K. K. Srinivasan and M. K. Unnikrishnan, "Radiation Protection by the Ocimum Flavonoids Orientin and Vicenin: Mechanisms of Action," Radiation Research, Vol. 154, No. 4, 2000, pp. 455-460.

http://dx.doi.org/10.1667/0033-7587(2000)154[0455:RPB $\mathrm{TOF}] 2.0 . \mathrm{CO} ; 2$

[13] D. Bagchi, M. Bagchi, S. J. Stohs, D. K. Das, S. D. Ray, C. A. Kuszynski, S. S. Joshi and H. G. Pruess, "Free Radicals and Grape Seed Proanthocyanidin Extract: Importance in Human Health and Disease Prevention," Toxicology, Vol. 148, No. 2-3, 2000, pp. 187-197. http://dx.doi.org/10.1016/S0300-483X(00)00210-9

[14] V. G. Makarov, M. N. Makarova and A. I. Selezneva, "Studying the Mechanism of Antioxidant Effect of Vitamins and Flavonoids," Voprosy Pitaniia, Vol. 74, No. 1, 2005, pp. 10-13.

[15] M. N. MakarovaV. G. Makarov, and I. G. Zenkevich, "Antiradical Activity of Flavonoids and Their Combination with Other Antioxidants," Farmatsiia, No. 2, 2004, pp. 30-32.

[16] N. Begum, N. R. Prasad, G. Kanimozhi and A. Q. Hasan, “Apigenin Ameliorates Gamma Radiation-Induced Cytogenetic Alterations in Cultured Human Blood Lymphocytes,” Mutation Research, Vol. 747, No. 1, 2012, pp. 7176.

[17] N. K. Janjua, A. Siddiqa, A. Yaqub, S. Sabahat, R. Qureshi and S. U. Haque, "Spectrophotometric Analysis of Flavonoid-DNA Binding Interactions at Physiological Conditions," Spectrochimica Acta. Part A. Molecular and Biomolecular Spectroscopy, Vol. 74, No. 5, 2009, pp. 1135-1137. http://dx.doi.org/10.1016/j.saa.2009.09.022

[18] E. Middleton Jr., C. Kandaswami and T. C. Theoharides, "The Effects of Plant Flavonoids on Mammalian Cells: Implications for Inflammation, Heart Disease, and Cancer,” Pharmacological Reviews, Vol. 52, No. 4, 2000, pp. 673-751.

[19] J. Castillo, O. Benavente-Garcia, J. Lorente, M. Alcaraz, A. Redondo, A. Ortuño and J. A. Del Rio, "Antioxidant Activity and Radioprotective Effects against Chromosomal Damage Induced in Vivo by X-Rays of Flavan3-ols (Procyanidins) from Grape Seeds (Vitis vinifera): Comparative Study versus Other Phenolic and Organic Compounds," Journal of Agricultural Food Chemistry, Vol. 46, No. 5, 2000, pp. 1738-1745. http://dx.doi.org/10.1021/jf990665o

[20] W. Greenrod and M. Fenech, "The Principal Phenolic and Alcoholic Components of Wine Protect Human Lymphocytes against Hydrogen Peroxide- and Ionizing RadiationInduced DNA Damage in Vitro,” Mutagenesis, Vol. 18, No. 2, 2003, pp. 119-126. http://dx.doi.org/10.1093/mutage/18.2.119
[21] H. Yoshioka, G. Akai, K. Yoshinaga, K. Hasegawa and H. Yoshioka, "Protecting Effect of a Green Tea Percolate and Its Main Constituents against Gamma Ray-Induced Scission of DNA," Bioscience, Biotechnology, and Biochemistry, Vol. 60, No. 1, 1996, pp. 117-119. http://dx.doi.org/10.1271/bbb.60.117

[22] H. Yoshioka, H. Kurosaki, K. Yoshinaga, K. Saito and H. Yoshioka, "Beta Ray-Induced Scission of DNA in Tritiated Water and Protection by a Green Tea Percolate and (-)-Epigallocatechin Gallate,” Bioscience, Biotechnology, and Biochemistry, Vol. 61, No. 9, 1997, pp. 1560-1563. http://dx.doi.org/10.1271/bbb.61.1560

[23] G. C. Jagetia and T. K. Reddy, "The Grapefruit Flavanone Naringin Protects against the Radiation-Induced Genomic Instability in the Mice Bone Marrow: A Micronucleus Study,” Mutation Research, Vol. 519, No. 1-2, 2002, pp. 37-48. http://dx.doi.org/10.1016/S1383-5718(02)00111-0

[24] K. N. Rithidech, M. Tungjai and E. B. Whorton, "Protective Effect of Apigenin on Radiation-Induced Chromosomal Damage in Human Lymphocytes," Mutation Research, Vol. 585, No. 1-2, 2005, pp. 96-104. http://dx.doi.org/10.1016/j.mrgentox.2005.04.003

[25] K. Shimoi, S. Masuda M. Furugori, S. Esaki and N. Kinae, "Radioprotective Effect of Antioxidative Flavonoids in Gamma-Ray Irradiated Mice,” Carcinogenesis, Vol. 15, No. 11, 1994, pp. 2669-2672.

http://dx.doi.org/10.1093/carcin/15.11.2669

[26] A. Harper, D. J. Kerr, A. Gescher and J. K. Chipman, "Antioxidant Effects of Isoflavonoids and Lignans, and Protection against DNA Oxidation,” Free Radical Research, Vol. 31, No. 2, 1999, pp. 149-160. http://dx.doi.org/10.1080/10715769900301661

[27] O. Benavente-Garcia, J. Castillo, J. Lorente and M. Alcaraz,"Radioprotective Effects in Vivo of Phenolics Extracted from Olea Europaea L. Leaves against X-RayInduced Chromosomal Damage: Comparative Study versus Several Flavonoids and Sulfur-Containing Compounds," Journal of Medicinal Food, Vol. 5, No. 3, 2002, pp. 125-135. http://dx.doi.org/10.1089/10966200260398152

[28] G. C. Jagetia and T. K. Reddy, "Modulation of RadiationInduced Alteration in the Antioxidant Status of Mice by Naringin,” Life Science, Vol. 77, No. 7, 2005, pp. 780794. http://dx.doi.org/10.1016/j.lfs.2005.01.015

[29] A. K. Akhmadieva, S. I. Zaichkina, R. K. Ruzieva and E. E. Ganassi, "The Protective Action of a Natural Preparation of Anthocyan (Pelargonidin-3,5-Diglucoside)," Radiobiologiia, Vol. 33, No. 3, 1993, pp. 433-435.

[30] T. A. Davis, T. K. Clarke, S. R. Mog and M. R. Landauer, "Subcutaneous Administration of Genistein Prior to Lethal Irradiation Supports Multilineage, Hematopoietic Progenitor Cell Recovery and Survival,” International Journal of Radiation Biology, Vol. 83, No. 3, 2007, pp. 141-151. http://dx.doi.org/10.1080/09553000601132642

[31] M. R. Landauer, V. Srinivasan and T. M. Seed, “Genistein Treatment Protects Mice from Ionizing Radiation Injury," Journal of Applied Toxicology, Vol. 23, No. 6, 2003, pp. 379-385. 
http://dx.doi.org/10.1002/jat.904

[32] N. Orsolić, V. Benković, A. Horvat-Knezević, N. Kopjar, I. Kosalec, M. Bakmaz, Z. Mihaljević, K. Bendelja and I. Basić, "Assessment by Survival Analysis of the Radioprotective Properties of Propolis and Polyphenolic Compounds,” Biological and Pharmaceutical Bulletin, Vol. 30, No. 5, 2007, pp. 946-951. http://dx.doi.org/10.1248/bpb.30.946

[33] S. A. Bol'shakova, G. G. Batulina and T. N. Tuzhilkova, "The Influence of Rowanberry Extract to Body Resistance to Radiation and Other Extremal Factors,” In: Radiation Injury and Its Modification, Nauka, Moscow, 1985, pp. 86-90.

[34] V. K. Singh, M. B. Grace, V. I. Parekh, M. H. Whitnall and M. R. Landauer, "Effects of Genistein Administration on Cytokine Induction in Whole-Body Gamma Irradiated Mice,” International Immunopharmacology, Vol. 9, No. 12, 2009, pp. 1401-1410.

[35] R. M. Day, M. Barshishat-Kupper, S. R. Mog, E. A. McCart, P. G. Prasanna, T. A. Davis and M. R. Landauer, "Genistein Protects against Biomarkers of Delayed Lung Sequelae in Mice Surviving High-Dose Total Body Irradiation,” Journal of Radiation Research, Vol. 49, No. 4, 2008, pp. 361-372. http://dx.doi.org/10.1269/jrr.07121

[36] P. Okunieff, S. Swarts, P. Keng, W. Sun, W. Wang, J. Kim, S. Yang, H. Zhang, C. Liu, J. P. Williams, A. K. Huser and L. Zhang, “Antioxidants Reduce Consequences of Radiation Exposure," Advances in Experimental Medicine and Biology, Vo. 614, Springer, Berlin, 2008, pp. 165178. http://dx.doi.org/10.1007/978-0-387-74911-2_20

[37] K. S. Chertkov and V. M. Petrov, "Pharmacological-Chemical Protection and Substitutive Therapy as Component of System of Radiation Safety for Cosmonauts in Mission to Mars,” Aviakosmicheskaia and Ekologicheskaia Medicina, Vol. 27, No. 5-6, 1993, pp. 32-37.

[38] N. D. Turner, L. A. Braby, J. Ford and J. R. Lupton, “Opportunities for Nutritional Amelioration of Radiation-Induced Cellular Damage,” Nutrition, Vol. 18, No. 10, 2002, pp. 904-912. http://dx.doi.org/10.1016/S0899-9007(02)00945-0

[39] B. M. Rabin, B. Shukitt-Hale, J. Joseph and P. Todd, "Diet as a factor in Behavioral Radiation Protection Following Exposure to Heavy Particles," Gravitational and Space Biology Bulletin, Vol. 18, No. 2, 2005, pp. 71-77.

[40] I. B. Ushakov and M. V. Vasin, "Radiation Protectors within the Radiation Safety System for Extended Duration Exploration Missions,” Aviakosmicheskaia and Ekologicheskaia Medicina, Vol. 45, No. 3, 2011, pp. 3-12.

[41] N. Orsolić, V. Benković, A. Horvat-Knezević, N. Kopjar, I. Kosalec, M. Bakmaz, Z. Mihaljević, K. Bendelja and I. Basić, "Assessment by Survival Analysis of the Radioprotective Properties of Propolis and Polyphenolic Compounds," Biological and Pharmaceutical Bulletin, Vol. 30, No. 5, 2007, pp. 946-951. http://dx.doi.org/10.1248/bpb.30.946

[42] Z. L. Fan, Z. Y. Wang, L. L. Zuo and S. Q. Tian, "Protective Effect of Anthocyanins from Lingonberry on Radiation-Induced Damages," International Journal of Environmental Research and Public Health, Vol. 9, No. 12, 2012, pp. 4732-4743. http://dx.doi.org/10.3390/ijerph9124732

[43] K. Pradeep, K. C. Ko, M. H. Choi, J. A. Kang, Y. J. Chung and S. H. Park, "Protective Effect of Hesperidin, a Citrus Flavanoglycone, against $\gamma$-Radiation-Induced Tissue Damage in Sprague-Dawley Rats," Journal of Medicinal Food, Vol. 15, No. 5, 2012, pp. 419-427.

http://dx.doi.org/10.1089/jmf.2011.1737

[44] H. Selye, “The Nature of Stress,” Basal Fact, Vol. 7, 1985, pp. 3-11.

[45] L. K. Garkavi, E. B. Kvakina, A. K. Mulatova and A. I. Shikhliarova, "Enhancement of Antitumor Resistance by Means of Small Doses of Adrenaline,” Voprosy Onkologii, Vol. 26, No. 6, 1980, pp. 48-53.

[46] D. G. Lindsay, "Nutrition, Hormetic Stress and Health," Nutrition Research Reviews, Vol. 182, No. 2, 2005, pp. 249-258. http://dx.doi.org/10.1079/NRR2005110

[47] A. Speciale, J. Chirafisi, A. Saija and F. Cimino, "Nutritional Antioxidants and Adaptive Cell Responses: An Update," Current Molecular Medicine, Vol. 11, No. 9, 2011, pp. 770-789. http://dx.doi.org/10.2174/156652411798062395

[48] P. Renard, M. D. Zachary, C. Bougelet, M. E. Mirault, G. Haegeman, J. Remacle and M. Raes, "Effect of Antioxidant Enzyme Modulations on Interleukin-1-Induced Nuclear Factor Kappa B Activation,” Biochemical Pharmacology, Vol. 53, No. 2, 1997, pp. 149-160.

[49] J. C. Chen, F. M. Ho, P. D. L. Chao, C. P. Chen, K. C. Jeng, H. B. Hsu, S. T. Lee, W. T. Wu and W. W. Lin, "Inhibition of iNOS Gene Expression by Quercetin Is Mediated by the Inhibition of IkappaB kinase, Nuclear Factor-kappa B and STAT1, and Depends on Heme Oxygenase-1 Induction in Mouse BV-2 Microglia,” European Journal of Pharmacology, Vol. 521, No. 1-3, 2005, pp. 9-20. http://dx.doi.org/10.1016/j.ejphar.2005.08.005

[50] I. Paur, T. R. Balstad, M. Kolberg, M. K. Pedersen, L. M. Austenaa, D. R. Jacobs amd R. Blomhoff, "Extract of Oregano? Coffe, Thyme, Clove, and Walnuts Inhibits NF-kappa B in Monocytes and in Transgenic Reporter Mice," Cancer Prevention Research (Philadelphia), Vol. 3, No. 5, 2010, pp. 653-663.

[51] S. R. Bornstein, M. Yoshida-Hiroi, S. Sotiriou, M. Levine, H. G. Hartwig, R. L. Nussbaum and G. Eisenhofer, "Impaired Adrenal Catecholamine System Function in Mice with Deficiency of the Ascorbic Acid Transporter (SVCT2)," FASEB Journal, Vol. 17, No. 13, 2003, pp. 1928-1930.

[52] P. Patak, H. S. Willenberg and S. R. Bornstein, "Vitamin C Is an Important Cofactor for both Adrenal Cortex and Adrenal Medulla," Endocrine Research, Vol. 30, No. 4, 2004, pp. 871-875. http://dx.doi.org/10.1081/ERC-200044126

[53] T. Valachovicova, V. Slivova and D. Sliva, "Cellular and Physiological Effects of Soy Flavonoids,” Mini Review of Medicinal Chemistry, Vol. 4, No. 8, 2004, pp. 881-887. http://dx.doi.org/10.2174/1389557043403387

[54] V. K. Singh, M. B. Grace, V. I. Parekh, M. H. Whitnall and M. R. Landauer, "Effects of Genistein Administration on Cytokine Induction in Whole-Body Gamma Irradiated Mice,” International Immunopharmacology, Vol. 9, No. 12, 2009, pp. 1401-1410. 
[55] Y. Z. Fang, S. Yang and G. Wu, "Free Radicals, AntiOxidants, and Nutrition,” Nutrition, Vol. 18, No. 10, 2002, pp. 872-879. http://dx.doi.org/10.1016/S0899-9007(02)00916-4

[56] K. J. Meyers, J. L. Rudolf and A. E. Mitchell, "Influence of Dietary Quercetin on Glutathione Redox Status in Mice,” Journal of Agricultural and Food Chemistry, Vol. 56, No. 3, 2008, pp. 830-836. http://dx.doi.org/10.1021/jf0723581

[57] S. Pal, C. Saha and S. K. Dey, "Studies on Black Tea (Camellia sinensis) Extract as a Potential Antioxidant and a Probable Radioprotector," Radiation and Environmental Biophysics, Vol. 52, No. 2, 2013, pp. 269-278. http://dx.doi.org/10.1007/s00411-013-0463-z

[58] D. Ghosh, S. Pal, C. Saha, A. K. Chakrabarti, S. C. Datta and S. K. Dey, "Black Tea Extract: A Supplementary Antioxidant in Radiation-Induced Damage to DNA and Normal Lymphocytes,” Journal of Environmental Pathology, Toxicology and Oncology, Vol. 31, No. 2, 2012, pp. 155-166.

http://dx.doi.org/10.1615/JEnvironPatholToxicolOncol.v3 $1 . \mathrm{i} 2.70$

[59] B. Frei and J. V. Higdon, "Antioxidant Activity of Tea Polyphenols in Vivo: Evidence from Animal Studies," The Journal of Nutrition, Vol. 133, No. 10, 2003, pp. 3275S3284S.

[60] K. Ullmann, A. M. Wiencierz, C. Müller, R. Thierbach, A. Steege, S. Toyokuni and P. Steinberg, "A High-Throughput Reporter Gene Assay to Prove the Ability of Natural Compounds to Modulate Glutathione Peroxidase, Superoxide Dismutase and Catalase Gene Promoters in V79 Cells," Free Radical Research, Vol. 42, No. 8, 2008, pp. 746-753. http://dx.doi.org/10.1080/10715760802337273

[61] M. K. Chung, A. Y. Kang, K. M. Lee, E. Oh, H. J. Jun, S. Y. Kim, J. H. Auh, T. V. Moon, S. J. Lee and K. H. Park, "Water-Soluble Genistin Glycoside Isoflavones Up-Regulate Antioxidant Metallothionein Expression and Scavenge Free Radicals," Journal of Agricultural and Food Chemistry, Vol. 54, No. 11, 2006, pp. 3819-3826. http://dx.doi.org/10.1021/jf060510y

[62] X. Gao, B. Wang, X. Wei, K. Men, F. Zheng, Y. Zhou, Y. Zheng, M. Gou, M. Huang, G. Guo, N. Huang, Z. Qian and Y. Wei, "Anticancer Effect and Mechanism of Polymer Micelle-Encapsulated Quercetin on Ovarian Cancer,” Nanoscale, Vol. 4, No. 22, 2012, pp. 7021-7030. http://dx.doi.org/10.1039/c2nr32181e

[63] A. K. Khaw, J. W. Yong, G. Kalthur and M. P. Hande, "Genistein Induces Growth Arrest and Suppresses Telomerase Activity in Brain Tumor Cells," Genes, Chromosomes and Cancer, Vol. 51, No. 10, 2012, pp. 961-974. http://dx.doi.org/10.1002/gcc.21979

[64] J. H. Lee, T. O. Khor, L. Shu, Z. Y. Su, F. Fuentes and A. N. Kong, "Dietary Phytochemicals and Cancer Prevention: Nrf2 Signaling, Epigenetics, and Cell Death Mechanisms in Blocking Cancer Initiation and Progression,” Pharmacology and Therapeutics, Vol. 137, No. 2, 2013, pp. 153171.

[65] W. Vanden Berghe, N. Dijsselbloem, L. Vermeulen, M. N. Ndlovu, E. Boone and G. Haegeman, "Attenuation of
Mitogen- and Stress-Activated Protein Kinase-1-Driven Nuclear Factor- $\kappa \mathrm{B}$ Gene Expression by Soy Isoflavones Does not Require Estrogenic Activity," Cancer Research, Vol. 66, No. 9, 2006, pp. 4852-4862. http://dx.doi.org/10.1158/0008-5472.CAN-05-2957

[66] A. Molteni, J. E. Moulder, E. P. Cohen, B. L. Fish, J. M. Taylor, P. A. Veno, L. F. Wolfe and W. F. Ward, "Prevention of Radiation-Induced Nephropathy and Fibrosis in a Model of Bone Marrow Transplant by an Angiotensin II Receptor Blocker,” Experimental Biology and Medicine (Maywood), Vol. 226, No. 11, 2001, pp. 10161023.

[67] M. Medhora, F. Gao, E. R. Jacobs and J. E. Moulder, "Radiation Damage to the Lung: Mitigation by AngiotensinConverting Enzyme (ACE) Inhibitors,” Respirology, Vol. 17, No. 1, 2012, pp. 66-71. http://dx.doi.org/10.1111/j.1440-1843.2011.02092.x

[68] L. Kma, F. Gao, B. L. Fish, J. E. Moulder, E. R. Jacobs and M. Medhora, “Angiotensin Converting Enzyme Inhibitors Mitigate Collagen Synthesis Induced by a Single Dose of Radiation to the Whole Thorax," Journal of Radiation Research, Vol. 53, No. 1, 2012, pp. 10-17. http://dx.doi.org/10.1269/jrr.11035

[69] I. E. Sklobovskaia, L. P. Zhavoronkov and B. V. Dubovik, "Effect of the Inhibition of Prostaglandin Biosynthesis on the Hematopoietic Status of Irradiated Mice," Radiobiologiia, Vol. 24, No. 1, 1984, pp. 56-59.

[70] M. V. Vasin, I. B. Ushakov, V. Kovtun, S. N. Komarova, L. A. Semenova and A. A. Galkin, "Comparative Effectiveness of Antioxidant Melatonin and Radioprotectors Indralin and Phenylephrine in Local Radiation Injuries," Radiatsionnaia Biologiia, Radioecologiia, Vol. 44, No. 1, 2004, pp. 68-71.

[71] F. Sieber, S. A. Muir, E. P. Cohen, B. L. Fish, M. Mäder, A. B. Schock, B. J. Althouse and J. E. Moulder, "Dietary Selenium for the Mitigation of Radiation Injury: Effects of Selenium Dose Escalation and Timing of Supplementation,” Radiation Research, Vol. 176, No. 3, 2011, pp. 366-374. http://dx.doi.org/10.1667/RR2456.1

[72] R. M. Day, T. A. Davis, M. Barshishat-Kupper, E. A. McCart, A. J. Tipton and M. R. Landauer, "Enhanced Hematopoietic Protection Fromradiation by the Combination of Genistein and Captopril,” Internatinal Immunopharmacology, Vol. 15, No. 2, 2013, pp. 348-356. http://dx.doi.org/10.1016/j.intimp.2012.12.029

[73] S. Fujisawa and Y. Kadoma, "Anti- and Pro-oxidant Effects of Oxidized Quercetin, Curcumin or Curcumin-Related Compounds with Thiols or Ascorbate as Measured by the Induction Period Method,” In Vivo, Vol. 20, No. 1, 2006, pp. 39-44.

[74] N. Miyoshi, K. Naniwa, T. Yamada, T. Osawa and Y. Nakamura, "Dietary Flavonoid Apigenin Is a Potential Inducer of Intracellular Oxidative Stress: The Role in the Interruptive Apoptotic Signal,” Archives of Biochemistry and Biophysics, Vol. 466, No. 2, 2007, pp. 274-282. http://dx.doi.org/10.1016/j.abb.2007.07.026

[75] W. Zhao and M. E. Robbins, "Inflammation and Chronic Oxidative Stress in Radiation-Induced Late Normal Tissue Injury: Therapeutic Implications,” Current Medicinal 
Chemistry, Vol. 16, No. 2, 2009, pp. 130-143. http://dx.doi.org/10.2174/092986709787002790

[76] K. Brusselmans, R. Vrolix, G. Verhoeven and J. V. Swinnen, "Induction of Cancer Cell Apoptosis by Flavonoids Is Associated with Their Ability to Inhibit Fatty Acid Synthase Activity," Journal of Biological Chemistry, Vol. 280, No. 7, 2005, pp. 5636-5645.

[77] D. W. Lamson and M. S. Brignall, “Antioxidants and Cancer Therapy II: Quick Reference Guide,” Alternative Me-

\section{Abbreviations and Acronyms}

Nrf2/Keap1 pathway-Signaling pathway involving the repressor protein Keap1 and the transcription factor nuclear factor-erythroid 2-related factor (Nrd2), which binds to the antioxidant response elements in the promoters of antioxidant enzymes and detoxifying enzymes, the global regulator of oxidative stress

Sirtuin/FoxO pathway-Signaling pathway in which sirtuin, nuclear famaly proteins, key regulators of cell defenses and survival in response to stress, deacetylates and represses FoxO (transcription factor Forkhead box O) dependent apoptosis

$N F-\kappa B$ - Transcription nuclear factor карраB dicine Review: A Journal of Clinical Therapeutic, Vol. 5, No. 2, 2000, pp. 152-163.

[78] V. Izzi, L. Masuelli, I. Tresoldi, P. Sacchetti, A. Modesti, F. Galvano and R. Bei, "The Effects of Dietary Flavonoids on the Regulation of Redox Inflammatory Networks," Frontiers in Bioscience (Landmark Ed), Vol. 17, No. 7, 2012, pp. 2396-2418. http://dx.doi.org/10.2741/4061

ERK-Extracellular signal-regulated kinase

$M E K$-Extracellular signal-regulated kinase (ERK) kinase

$A R S$ - Acute radiation syndrome

STAT1 - A member of the Signal Transducers and Activators of Transcription family of transcription factors iNOS-Inducible isoform of nitric oxide synthases

$G$-CSF-Granulocyte-colony stimulant factor

IL-6-Interleukine-6

DNA-Deoxyribonucleic acid

$U V$-radiation-Ultraviolet radiation

$C A$ — chromosome aberrations 